Volume 7, No. 12 December 2019

International Journal of Emerging Trends in Engineering Research

Available Online at http://www.warse.org/IJETER/static/pdf/file/ijeter237122019.pdf

https://doi.org/10.30534/ijeter/2019/237122019

\title{
Pharmacodynamics of the Drug Based on Arthrobotrys Oligospora
}

\author{
N.S. Yakovleva ${ }^{1}$, G.A. Nozdrin $^{2}$, M.S. Yakovleva ${ }^{3}$, S.N. Tishkov ${ }^{4}$, A.I. Lelyak ${ }^{5}$ \\ ${ }^{1}$ Novosibirsk State Agrarian University, Novosibirsk, Russian Federation \\ ${ }^{2}$ Novosibirsk State Agrarian University, Novosibirsk, Russian Federation \\ ${ }^{3}$ Novosibirsk State Agrarian University, Novosibirsk, Russian Federation \\ ${ }^{4}$ Novosibirsk State Agrarian University, Novosibirsk, Russian Federation \\ ${ }^{5}$ SPC Issledovatelsky tsentr ("Research center"), Koltsovo Science Town, Novosibirsk region, Russian Federation
}

\begin{abstract}
The effect of new drug Vetom 20.76 based on predatory fungus Arthrobotrys oligospora on the intensity of live weight growth, the dynamics of changes in the protein exchange, and the correlation between these in the geese was studied. The drug was administered internally for three months in the dosages of 2,10 , and $30 \mu \mathrm{l}$ per $1 \mathrm{~kg}$ of the geese body weight. When Vetom 20.76 was administered in the dosages of 10 and $30 \mu \mathrm{l} / \mathrm{kg}$ of the body weight, an intensive weight gain was registered along with an increased concentration of total protein and albumins in the blood serum. The maximum increase in the studied parameters was registered when Vetom was administered in the dosage of $10 \mu \mathrm{l} / \mathrm{kg}$ of the body weight, and the maximum increase in albumins - in the dosage of $2 \mu \mathrm{l} / \mathrm{kg}$ of the body weight. Intensive weight gain upon the use of Vetom 20.76 in the dosage of $2 \mu \mathrm{l} / \mathrm{kg}$ of the body weight occurred in the conditions of protein and albumins deficiency; when the drug was used in the dosages of 10 and $30 \mu \mathrm{l} / \mathrm{kg}$ of the body weight, this effect was not registered. In the geese in the experimental groups, the concentration of globulins in the blood serum decreased when the drug was used in low dosages at the beginning of the experiment. No side effects were observed during the study of the drug. When Vetom 20.76 was used in the dosage of $30 \mu \mathrm{l} / \mathrm{kg}$, the concentration of globulins increased, and the concentration of albumins in the blood serum decreased.
\end{abstract}

Key words: the absolute body weight, albumins, total protein, Vetom, globulins, correlation, carnivorous fungus Arthrobotrys oligospora.

\section{INTRODUCTION}

The normal flora of the intestines promotes good digestion, improves metabolism, and creates resistance to pathologies of various nature. It ensures high immunity by increasing the titers of specific antibodies. An important feature is reduced morbidity and productivity losses associated with the technology stress [1-4]. Therefore, studying the drugs that modulate the normal microflora background is an important challenge for livestock breeding and veterinary industry [5-9].

Probiotic drugs have a positive effect on the animal organism by improving the intestinal microbial balance, and stimulating the metabolic and immune processes [10-14]. Manufacturers of feed for all kinds of animals and poultry often use drugs based on lactobacilli, bifidobacterial, and apathogenic bacilli [15-17].

Studying the reaction of the organism to the introduction of probiotic drugs with a wide spectrum of action, and their effect on the metabolic processes, the nutritional value, and the meat productivity of poultry is of great theoretical and practical interest [18-20]. Liquefied and powdered probiotics based on bacilli have been sufficiently studied, while drugs based on the apathogenic fungus Arthrobotrys oligospora have virtually not been studied [21-24].

Therefore, studying the correlational interaction of the weight gain intensity and the biochemical parameters of blood in the geese upon the use of the new drug based on predatory fungus Arthrobotrys oligospora is an important and urgent issue.

The work was aimed at studying the correlation of the weight gain intensity and the biochemical parameters of blood in the geese upon the use of the new drug based on predatory fungus Arthrobotrys oligospora.

\section{PROPOSED METHODOLOGY}

\subsection{General description}

The object of the study was the Vetom 20.76 drug based on predatory fungus Arthrobotrys oligospora. The subjects of the study were Chinese white geese at the age of $2-10$ weeks. To achieve the objective of the study by the principle of analog pairs, a reference and three experimental groups were formed, seven goslings in each. The goslings in experimental groups 1 -3 received the drug internally, once a day in the dosages of 2,10 , and $30 \mu \mathrm{l} / \mathrm{kg}$ of the body weight, respectively, for three months. The goslings in the reference group did not receive the drug

\subsection{Algorithm}

Vetom 20.76 is a brown liquid with a characteristic odor. Light-brown sediment is allowed. 
The goslings were kept in ventilated cages following the European Convention for keeping vertebrate in $3 \times 4 \mathrm{~m} 2$ cages. The temperature in the cages corresponded to the ambient temperature in the summer. Lighting and ventilation were natural. The goslings had free access to the water. Meadow hay was used for litter.

Numerical data were statistically processed using the biometric method in Microsoft Excel. The correlation dependencies were calculated by Spearman (1904). The veracity of the differences between the groups in terms of quantitative traits was assessed using Dunn's q-test.

\section{RESULT ANALYSIS}

Under the effect of the studied microbial drug, the geese growth rate changed (Table 1). Before the experiment, the weights of the geese in experimental and reference groups had not been veraciously different. On the 20th day of the experiment, the absolute bodyweight of the geese in experimental groups $1-3$ was higher by $25.94,42.98$ (P < $0.01)$, and $47.85(\mathrm{P}<0.01) \%$, respectively, than their analogs in the reference group. On the 50th day of the experiment, the bodyweight of the geese in experimental groups $1-3$ was higher by 17.18, $24.96(\mathrm{P}<0.01)$, and $24.43(\mathrm{P}<0.05) \%$, respectively, than that of their analogs in the reference group. On the 80th day of the experiment, the bodyweight of the geese in experimental groups $1-3$ was higher by $5.58,10.60$ $(\mathrm{P}<0.05)$, and $11.82 \%$, respectively, than that of their analogs in the reference group. On the 100th day of the experiment, the bodyweight of the geese in experimental groups $1-3$ was higher by $8.29,9.92$, and $8.23 \%$, respectively, than that of their analogs in the reference group. Thus, the studied drug increased the bodyweight with the peak of weight gain on days $20-40$ of the experiment, and then the rate of weight gain in experimental groups $1-3$ started approaching the value in the reference group.

The highest rate of live weight gain was registered when Vetom was used in the dosages of 10 and $30 \mu \mathrm{l} / \mathrm{kg}$ of the body weight.

Table 1: The dynamics of the total weight gain in the experimental geese, $g$

\begin{tabular}{|l|l|l|l|l|l|}
\hline \multirow{2}{*}{ Groups } & Age, days & \multicolumn{5}{|l|}{} \\
\cline { 2 - 6 } & 0 days & 20 days & 50 days & 80 days & 110 days \\
\cline { 2 - 5 } & Me \pm me & Me \pm me & Me \pm me & Me \pm me & Me \pm me \\
\hline \multirow{2}{*}{ Reference } & $626.50 \pm$ & $1,118.00 \pm$ & $2,620.00 \pm$ & $3,690.00 \pm$ & $3,681.00 \pm$ \\
& 16.03 & 27.37 & 61.02 & 96.16 & 121.51 \\
\hline \multirow{2}{*}{ Experimental 1 } & $723.00 \pm$ & $1,408.00 \pm$ & $3,070.00 \pm$ & $3,896.00 \pm$ & $3,986.00 \pm$ \\
& 57.99 & 111.32 & 248.33 & 332.89 & 329.55 \\
\hline \multirow{2}{*}{ Experimental 2 } & $837.50 \pm$ & $1,598.50 \pm$ & $3,274.00 \pm$ & $4,081.00 \pm$ & $4,046.00 \pm$ \\
& $18.75 * *$ & $62.93 * *$ & $102.41 * *$ & $116.82 *$ & 121.80 \\
\hline \multirow{2}{*}{ Experimental 3 } & $1,000.00 \pm$ & $1,653.00 \pm$ & $3,260.00 \pm$ & $4,126.00 \pm$ & $3,984.00 \pm$ \\
& $28.43 * *$ & $48.39 * *$ & $65.48 *$ & 99.01 & 97.45 \\
\hline
\end{tabular}

Note. Here and below: $* \mathrm{P}<0.05 ; * * \mathrm{P}<0.01 ; * * * \mathrm{P}<0.001$.

The change in the concentration of total protein in the blood serum of the geese in the experimental groups did not exceed the physiological norm (Table 2). On the 50th day of the experiment, the total protein concentration in the blood serum of the geese in experimental groups $1-2$ was lower by 1.56 and $6.98 \%$, respectively, and of the geese in experimental group 3 - higher by $1.95 \%$ than that of the analogs from the reference group. On the 80th day of the experiment, with increasing the duration of using the drug, the total protein concentration in the blood serum of the geese in experimental groups $1-3$ was lower by $2.80,9.09$, and $2.42 \%$, respectively, than that in the analogs in the reference group. On the 100th day of the experiment, the total protein concentration in the blood serum of the geese in experimental groups $1-3$ was lower by $4.18,9.34$ and $2.38 \%$, respectively, than that in the analogs in the reference group.

Thus, the studied drug slightly decreased the concentration of total protein in the blood serum of the experimental geese, compared to the reference, within the physiological norm. The most pronounced changes were registered when Vetom 20.76 was used in the dosages of 2 and $30 \mu \mathrm{l} / \mathrm{kg}$ of the body weight. 
N.S. Yakovleva et al., International Journal of Emerging Trends in Engineering Research, 7(12), December 2019, 861 - 866

Table 2: The dynamics of total protein concentration in the blood serum of the experimental geese, g/l

\begin{tabular}{|l|l|l|l|}
\hline \multirow{2}{*}{ Group } & Age, days & 80 days & 110 days \\
\cline { 2 - 4 } & 50 days & $58.48 \pm$ & $60.40 \pm$ \\
\multirow{2}{*}{ Reference } & $55.85 \pm$ & 1.26 & 1.44 \\
\hline \multirow{2}{*}{ Experimental 1 } & 1.27 & $56.84 \pm$ & $57.87 \pm$ \\
& $54.98 \pm$ & 4.66 & 4.84 \\
\hline \multirow{2}{*}{ Experimental 2 } & 4.46 & $53.16 \pm$ & $54.76 \pm$ \\
& $51.95 \pm$ & 1.15 & 1.15 \\
\hline \multirow{2}{*}{ Experimental 3 } & 1.14 & $57.06 \pm$ & $58.96 \pm$ \\
& $56.94 \pm$ & 1.42 & 1.51 \\
\hline
\end{tabular}

Studying the correlations of the absolute body weight and protein concentration in the blood serum of geese showed that in the reference and experimental group 3, a statically positive correlation had been observed throughout the experiment.

With that, in the geese in experimental group 1, it was negative, and in the geese in experimental group 2, it varied: first, reverse, and then straight (Table 3). This is evidence of the fact that in the geese that did not receive the drug, the weight was mainly gained due to protein; this effect persisted when the drug was administered in the dosage of $30 \mu \mathrm{l} / \mathrm{kg}$ of the body weight. When the studied drug was used in a lower dosage, the metabolic processes of macronutrients diversified toward the weight gain caused by the organic matter of nonprotein nature (lipids, carbohydrates). Since the main organic accumulate of the fungi is presented by lipid fractions, a conclusion can be made that the changes in the metabolic processes upon using the studied drug in low dosages occurred due to the fungal lipid accumulation. Since at high dosages, the metabolic processes return to the initial protein-dependent model, a conclusion can be made that adhesion of the component of the drug sharply reduced. This suggests that under the action of Vetom 20.76, protein accumulation occurs.

Table 3: Correlation between the macronutrients in the blood serum and the weight gain in the geese with the use of Vetom 20.76

\begin{tabular}{|c|c|c|c|c|c|c|}
\hline \multirow[b]{2}{*}{ Group } & \multicolumn{6}{|c|}{$\begin{array}{l}\text { Correlation indicators } \\
\text { (the numerator - on the 50th day, the denominator - on the 110th day) }\end{array}$} \\
\hline & 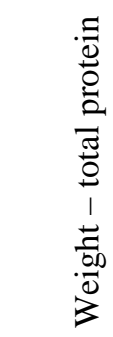 & 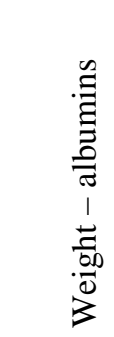 & 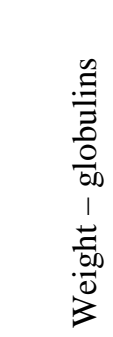 & 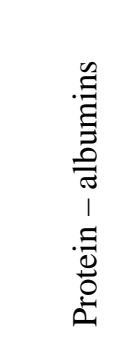 & 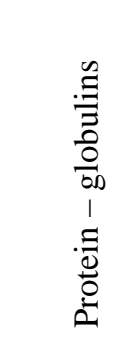 & 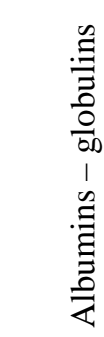 \\
\hline 1 & 2 & 3 & 4 & 5 & 6 & 7 \\
\hline Reference & $\begin{array}{l}0.17 * \\
0.19 *\end{array}$ & $\begin{array}{l}0.48 * \\
0.51 *\end{array}$ & $\begin{array}{l}-0.21 * \\
-0.25 *\end{array}$ & $\begin{array}{l}0.33 * \\
0.09 *\end{array}$ & $\begin{array}{l}0.53 * \\
0.09 *\end{array}$ & $\begin{array}{l}-0.61 * \\
-0.69 *\end{array}$ \\
\hline Experimental 1 & $\begin{array}{l}-0.73 * \\
-0.69 * \\
\end{array}$ & $\begin{array}{l}-0.56^{*} \\
-0.35^{*}\end{array}$ & $\begin{array}{l}0.17^{*} \\
-0.10^{*}\end{array}$ & $\begin{array}{l}0.43 * \\
0.53 *\end{array}$ & $\begin{array}{l}0.15^{*} \\
0.53 *\end{array}$ & $\begin{array}{l}-0.83 * \\
-0.78 *\end{array}$ \\
\hline Experimental 2 & $\begin{array}{l}-0.11 * \\
0.94\end{array}$ & $\begin{array}{l}0.03 * \\
0.69 \\
\end{array}$ & $\begin{array}{l}-0.07^{*} \\
0.84\end{array}$ & $\begin{array}{l}0.51 * \\
0.65 *\end{array}$ & $\begin{array}{l}0.87 \\
0.65^{*}\end{array}$ & $\begin{array}{l}-0.88^{*} \\
0.34 *\end{array}$ \\
\hline Experimental 3 & $\begin{array}{l}0.81 \\
0.75\end{array}$ & $\begin{array}{l}-0.25^{*} \\
-0.30 *\end{array}$ & $\begin{array}{l}0.73 \\
0.63 *\end{array}$ & $\begin{array}{l}-0.28 * \\
-0.36 *\end{array}$ & $\begin{array}{l}0.82 \\
-0.36\end{array}$ & $\begin{array}{l}-0.80 * \\
-0.36\end{array}$ \\
\hline
\end{tabular}

In the geese in the reference group throughout the experiment, the concentration of albumins in the blood serum below the physiological norm was registered, while in the geese in the experimental groups, this indicator was within the physiological norm (Table 4). On the 50th day of the experiment, the concentration of albumins in the blood serum of the geese in experimental groups $1-3$ was higher by $74.05,51.69$, and $37.95 \%$, respectively, than that in the analogs in the reference group. On the 80th day of the experiment, the concentration of albumins in the blood serum 
of the geese in experimental groups $1-3$ was higher by 70.91 , 53.48 , and $40.48 \%$, respectively, than that in the analogs in the reference group. On the 110th day of the experiment, the concentration of albumins in the blood serum of the geese in experimental groups $1-3$ was higher by $69.00,49.13$, and $40.07 \%$, respectively, than that in the analogs in the reference group.

Thus, the Vetom 20.76 drug brings the albumins concentration in the blood serum of the geese back to the limits of the physiological norm. The highest changes within the physiological norm were registered when Vetom 20.76 was used in the dosage of $2 \mu \mathrm{l} / \mathrm{kg}$ of the body weight.

In studying the correlations of the absolute body weight and the concentration of albumins, it was found that in the reference group and experimental group 3, statically veracious positive correlation throughout the experiment had been registered. With that, in the geese in experimental group 1 , the correlation of albumins and the absolute body weight throughout the entire experiment had the opposite direction, however, at the beginning of the experiment, it had been statistically veracious, and in the geese in experimental group 2 , the correlation of albumins and the absolute body weight was positive throughout the experiment (Table 3). This is evidence of the fact that in the geese that did not receive the drug, the weight was mainly gained due to the albumin fraction of protein; a similar effect was observed when the drug was administered in the dosage of $30 \mu \mathrm{l} / \mathrm{kg}$ of the body weight. This effect exactly mimicked the correlation interaction of the weight and the total protein content in blood serum. This suggests that albumin exchange intensifies only if high dosages are used.

However, a positive correlation of protein and albumins in blood serum of the geese was registered in the reference group and experimental groups $1-2$, and in experimental group 3 , the correlation of these parameters was negative (Table 3).

Table 4: The dynamics of albumins concentration in the blood serum of the geese under the action of Vetom 20.76, \%

\begin{tabular}{|l|l|l|l|}
\hline \multirow{2}{*}{ Group } & Age, days & 80 days & 110 days \\
\cline { 2 - 4 } & 50 days & $9.70 \pm$ & $10.65 \pm$ \\
\multirow{2}{*}{ Reference } & $9.17 \pm$ & 1.44 & 1.55 \\
\hline \multirow{2}{*}{ Experimental 1 } & 1.42 & $16.57 \pm$ & $17.99 \pm$ \\
& $15.96 \pm$ & 2.31 & 2.57 \\
\hline \multirow{2}{*}{ Experimental 2 } & 2.18 & $14.88 \pm$ & $15.88 \pm$ \\
& $13.91 \pm$ & 1.37 & 1.39 \\
\hline \multirow{2}{*}{ Experimental 3 } & 1.16 & $13.62 \pm$ & $14.91 \pm$ \\
& $12.65 \pm$ & 1.43 & 1.50 \\
\hline
\end{tabular}

Under the action of the studied drug, the concentration of globulins in the blood serum of the geese changed. Throughout the experiment, in the geese in experimental groups $1-2$, the concentration of this fraction of protein was within the physiological norm, while in the reference group and experimental group 3, hyperglobulinemia was observed (Table 5). On the 50th day of the experiment, the globulins concentration in the blood serum of the geese in experimental groups $1-2$ was lower by 10.78 and $14.34 \%$, respectively, and of the geese in experimental group 3 - higher by $3.81 \%$ than that of the analogs from the reference group, where this indicator was registered below the physiological norm. On the 80th day of the experiment, the total protein concentration in the blood serum of the geese in experimental groups $1-2$ was lower by 13.91 and $16.63 \%$, respectively, and of the geese in experimental group 3 - higher by $3.41 \%$ than that of the analogs from the reference group. On the 100th day of the experiment, the globulins concentration in the blood serum of the geese in experimental groups $1-3$ was lower by 18.50 , 19.95 , and $3.06 \%$, respectively, than that in the analogs in the reference group.

Table 5: The dynamics of globulins concentration in the blood serum of the experimental geese, $\%$

\begin{tabular}{|l|l|l|l|}
\hline \multirow{2}{*}{ Group } & Age, days & 80 days & 110 days \\
\cline { 2 - 4 } & 50 days & $45.14 \pm$ & $48.11 \pm$ \\
\multirow{2}{*}{ Reference } & $43.74 \pm$ & 1.71 & 2.07 \\
\hline \multirow{2}{*}{ Experimental 1 } & 1.59 & $38.86 \pm$ & $39.21 \pm$ \\
& $39.02 \pm$ & 3.72 & 3.79 \\
\hline \multirow{2}{*}{ Experimental 2 } & 3.58 & $37.64 \pm$ & $38.51 \pm$ \\
& $37.47 \pm$ & 2.24 & 2.32 \\
\hline \multirow{2}{*}{ Experimental 3 } & 2.00 & $46.68 \pm$ & $46.64 \pm$ \\
& $45.40 \pm$ & 2.33 & 2.49 \\
\hline
\end{tabular}


Thus, the studied drug decreased the concentration of globulins in the blood serum of the geese when used in the dosage of 2 and $10 \mathrm{ml} / \mathrm{kg}$ of the bodyweight at the beginning of the experiment, after which these doses could not maintain higher concentrations, compared to the reference. Under the action of the highest studied dosage of $30 \mu \mathrm{l} / \mathrm{kg}$, the concentration of globulins was higher than the reference.

Studying the correlations of the absolute body weight and the concentration of globulins showed that static negative correlation had existed in the reference group throughout the experiment. With that, in the geese in experimental groups 1 to 3 , both positive static and variable correlations were observed (Table 3). This is evidence of the fact that intensive weight gain in the geese that did not receive the drug was associated with a decrease in the concentration of globulins in the blood serum. The studied drug partially reduced this effect in the studied dosages of $2 \mu \mathrm{l} / \mathrm{kg}$ of the body weight and made it completely disappear after using the studied dosages of 30 $\mu \mathrm{l} / \mathrm{kg}$ of the body weight.

It is also noted that in the reference group and experimental groups $1-2$, the concentration of total protein and globulin in blood serum had direct correlation throughout the experiment, and in experimental group 3, this effect was registered only at the beginning of the experiment (Table 3 ). This suggests that after the prolonged use in a high dosage, the Vetom 20.76 drug changes the protein exchange. Albumin inversely correlated with globulins in the reference group and experimental groups 1 and 3 in all periods of the study. In the geese in experimental group 2, this trend was observed only at the beginning of the study. Albumins and globulins are not traditionally correlating indicators; however, in the study, an increase in albumins is mainly due to globulins deficiency, which was evidence of the fact that any need in immune bodies was compensated for by albumins.

\section{CONCLUSION}

1. Vetom 20.76 based on Arthrobotrys oligospora promotes intensive weight gain in the first days of its administration. The highest values are observed when the drug is administered in the dosages of 10 and $30 \mu \mathrm{l} / \mathrm{kg}$ of the body weight.

2. An increased concentration of total protein and albumins in the blood serum was noted. The highest concentrations of total protein were registered upon administration of Vetom 20.76 in the dosage of 2 and $30 \mu 1 / \mathrm{kg}$ of the body weight, and the maximum increase in albumins - in the dosage of $2 \mu \mathrm{l} / \mathrm{kg}$ of the body weight. There are inverse correlations between the concentration of total protein and albumins in the blood serum.

3. The drug based on predatory fungus Arthrobotrys oligospora decreases the concentration of globulins in the blood serum of the geese when administered in the dosages of 2 and $10 \mathrm{ml} / \mathrm{kg}$ of the body weight in the initial period of administration. In the dosage of $30 \mu \mathrm{l} / \mathrm{kg}$ the body weight, Vetom 20.76 increases the concentration of globulins in the blood serum of the geese.

\section{REFERENCES}

1. V.V. Gushchin. Razvitie promyshlennoi pererabotki myasa ptitsy $\mathrm{v}$ Rossii [Development of poultry meat industrial processing in Russia]. Meat industry, Vol. 6, pp. $11-13,2009$.

2. S.A. Imangulov, I.A. Egorov, T.M. Okolelova. Rekomendatsii po kormleniyu selskokhozyaistvennoi ptitsy [Recommendations for poultry feeding]. Sergiev Posad, VNITIP, p. 68, 2000.

3. S.F. Sukhanova, I.G. Kornienko. Pokazateli estestvennoi rezistentnosti gusyat-broilerov, potreblyavshikh Levisel SB plyus [Indicators of the natural resistance of the broiler goslings' that were administered Levisel SB plus]. Bulletin of the Altai State Agrarian University, Vol. 5(151), pp. 103 - 108, 2017.

4. L. Zucconi, C. Ripa, L. Selbmann, S. Onofri. Effects of uv on the Spores of the Fungal Species Arthrobotrys oligospora and A. ferox. Polar Biology, Vol. 25(7), pp. $500-505,2002$. https://doi.org/10.1007/s00300-002-0371-1

5. A.B. Ivanova, A.G. Nozdrin, A.I. Shevchenko. Probiotiki serii vetom v ptitsevodstve dlya povysheniya produktivnosti i kachestva produktsii [Vetom probiotics in poultry breeding for improving the productivity and the quality of the product]. Efficient and safe drugs in veterinary medicine: III International Congress of Veterinary pharmacologists and toxicologists. SPb., pp. $196-198,2014$.

6. G.A. Nozdrin, T.G. Kazantseva, A.B. Ivanova, A.G. Nozdrin, O.Y. Ledeneva, A.I. Lelyak, A.A. Lelyak. Intensivnost rosta gusei pri ispolzovanii vetoma 13.1 [Geese growth intensity upon administration of Vetom 13.1]. Achievements of science and technology in agriculture, Vol 10, pp. $71-72,2011$.

7. G.A. Nozdrin, A.A. Lelyak, E.P. Rafikov, N.V. Revkov. Opredelenie mestnogo rezorbtivnogo deistviya novogo probioticheskogo preparata vetom 21.77 [Determination of the local resorptive action of new probiotic drug Vetom 21.77]. In collection: Actual problems of the agroindustrial complex. Collection of works for the scientific-practical conference of teachers, students, and graduate students dedicated to the 80th anniversary of the Novosibirsk State Agrarian University. The Novosibirsk State Agrarian University, pp. 390 - 395, 2016.

8. Y.S. Roiter, A.F. Lukyanov, V.V. Gerasimenko. Nauchnye i prakticheskie aspekty razvedeniya gusei [Scientific and practical aspects of geese breeding]: monograph. Moscow: Publishing House "All Sergiev Posad", p. 204, 2004.

9. K.Y. Sokolova, I.V. Solovieva, G.I. Grigorieva. Nauchnoe obosnovanie neobkhodimosti ispolzovaniya probiotikov $\mathrm{v}$ ptitsevodcheskikh khozyaistvakh 
N.S. Yakovleva et al., International Journal of Emerging Trends in Engineering Research, 7(12), December 2019, 861 - 866

[Scientific substantiation for the need to use probiotics at poultry farms]. BIO, Vol. 10, pp. $6-7,2005$.

10. G.A. Nozdrin, A.I. Lelyak, A.I. Shevchenko. Deistvie probiotikov vetom $1.1 \mathrm{i}$ vetom 13.1 na nekotorye pokazateli morfologii krovi i estestvennoi rezistentnosti gusei [The effect of probiotics Vetom 1.1 and Vetom 13.1 on certain indicators of blood morphology and the natural resistance of geese]. News of NSAU, Vol. 8, pp. 24-26, 2008.

11. G.A. Nozdrin. Probiotiki na osnove Bacillus subtillis i ikh rol $\mathrm{v}$ podderzhanii zdorovya zhivotnykh raznykh vidov [Bacillus subtillis-based probiotics and their role in maintaining the health of animals of various species]. Siberian Bulletin of Agricultural Science, Vol. 7, pp. 67 68, 2007.

12. G.A. Nozdrin, A.B. Ivanova, O.Y. Ledeneva, D.A. Odnoshevsky, A.I. Shevchenko. Tekhnologicheskie aspekty primeneniya probioticheskikh preparatov [Technological aspects of using probiotic drugs]. New probiotic and immune-modulating drugs in veterinary medicine: proceedings of the Russian scientific-practical conference NSAU. Novosibirsk, pp. 55 - 56, 2003.

13. B.F. Silva, J.R. Carrijo-Mauad, F.R. Braga, A.K. Campos, J.V. Araújo, A.F. Amarante. Efficacy of Duddingtonia flagrans and Arthrobotrys robusta in controlling sheep parasitic gastroenteritis. Parasitology Research, Vol. 106(6), pp. 1343-1350, 2010. https://doi.org/10.1007/s00436-010-1805-2

14. U.B. Singh, R.K. Singh, J.S. Srivastava, A. Sahu, M.C. Manna, D.P. Singh, K.K. Meena. Evaluation of Biocontrol potential of Arthrobotrys oligospora against meloidogyne Graminicola and Rhizoctonia solani in rice (Oryza sativa 1.). Biological Control, Vol. 60(3), pp. 262-270, 2012. https://doi.org/10.1016/j.biocontrol.2011.10.006

15. S.F. Sukhanova, A.G. Makhalov. Probiotiki serii Vetom v sostave kombikormov dlya gusyat-broilerov [Probiotics of the Vetom series in the feed for broiler goslings]. News of the Kurgan State Agricultural Academy, Vol 3(11), 2014, pp. $59-62$.

16. G.R. Tsapalova, A.F. Khabirov. Vozrastnye izmeneniya gemotalogicheskikh pokazatelei i mikrobiologicheskogo statusa gusyat-broilerov pri ispolzovanie probiotikov [Age-related changes of the hematological indices and the microbiological status of broiler goslings upon the use of probiotics]. News of the Bashkir State Agrarian University, pp.-31 - 34, 2014.

17. A.G. Koshchaev, Y.A. Lysenko, M.P. Semenenko, E.V. Kuzminova, I.A. Egorov, E.J. Javadov. Engineering and Development of Probiotics for Poultry Industry. Asian Journal of Pharmaceutics, Vol. 12(4), pp. S1179-S1185, 2018.

18. G.A. Nozdrin, A.B. Ivanov, A.G. Nozdrin, A.I. Shevchenko. Farmakologicheskie aspekty primeneniya probiotikov na osnove Bac. subtilis dlya stimulyatsii rosta zhivotnykh [Pharmacological aspects of using of probiotics based on Bac. subtilis for stimulating animals' growth]. New pharmacological drugs in veterinary medicine: proceedings of the international scientific-practical conference. SPb., pp. 27 - 28, 2003.

19. G.A. Nozdrin, A.I. Shevchenko, S.A. Shevchenko. Fiziologicheskii status i produktivnost gusei pri primenenii probiotikov [Physiological status and productivity of geese upon the use of probiotics]: monograph. Novosibirsk State Agrarian University Novosibirsk: RC NSAU "Zolotoy Kolos", p. 194, 2017.

20. G.A. Nozdrin, E.R. Rafikova. Evaluation of Allergic Effect of a new Probiotic Preparation vetom 21.77. Advances in Agricultural and Biological Sciences, Vol. 3(4), pp. 35-39, 2017. https://doi.org/10.22406/aabs-17-3.4-35-39

21. A.I. Shevchenko, G.A. Nozdrin, A.B. Ivanova, A.I. Lelyak. Probiotiki na osnove Bacillus subtilis $i$ neorganicheskaya forma selena kak stimulyatory rosta myasnykh gusei [Bacillus subtilis-based probiotics and inorganic form of selenium as the growth promoters of meat geese]. News of the Novosibirsk State Agrarian University, Vol. 3(15), pp. 105 - 108, 2010.

22. S.V. Shulgin. Produktivnost gusyat-broilerov pri ispolzovanie probiotikov [Productivity of broiler goslings with the use of probiotics]. News of the Kurgan State Agricultural Academy, Vol. 3(3), pp. 61 - 63, 2012.

23. A.S. Fernandez, M. Larsen, J. Wolstrup, J. Gronvold, P. Nansen, H. Bjorn. Growth rate and Trapping Efficacy of nematode-trapping fungi under Constant and Fluctuating temperatures. Parasitology Research, Vol. 85(8-9), pp. 661-668, 1999. https://doi.org/10.1007/s004360050611

24. Y. Zhang, Z.F. Yu, J. Xu, K.Q. Zhang. Divergence and Dispersal of the nematode-trapping fungus Arthrobotrys oligospora from China. Environmental Microbiology Reports, Vol. 3(6), pp. 763-773, 2011. https://doi.org/10.1111/j.1758-2229.2011.00297.x 